\title{
IMPLEMENTASI GERAKAN LITERASI SEKOLAH DI SMP NEGERI 4 KOTA BENGKULU
}

\author{
Noven Handani Wirawan, Agus Trianto, dan Gumono \\ Program Studi Pendidikan Bahasa Indonesia \\ Jurusan Pendidikan Bahasa dan Seni \\ FKIP Universitas Bengkulu \\ noven_2handani@yahoo.com
}

\begin{abstract}
Abstrak
Tujuan penelitian ini adalah untuk mendeskripsikan implementasi Gerakan Literasi Sekolah di SMP Negeri 4 Kota Bengkulu. Penelitian ini menggunakan metode deskriptif dengan pendekatan kualitatif. Data yang diperoleh berupa informasi mengenai pelaksanaan Gerakan Literasi Sekolah serta hal-hal yang memengaruhi pelaksanaan Gerakan Literasi Sekolah. Sumber data pada penelitian ini yakni kepala sekolah, wakil kepala kurikulum, kepala perpustakaan, guru Bahasa Indonesia, serta peserta didik. Teknik pengumpulan data menggunakan teknik observasi, wawancara, dan dokumentasi. Teknik analisis data menggunakan 1) reduksi data, 2) penyajian data, dan 3) penarikan kesimpulan/verifikasi. Hasil penelitian menunjukkan bahwa SMP Negeri 4 Kota Bengkulu telah melaksanakan beberapa program literasi, seperti 1) kegiatan 15 menit membaca buku nonpelajaran, 2) jurnal membaca, 3) penghargaan pengunjung perpustakaan, 4) sudut baca dan pondok belajar, serta 5) kunjungan perpustakaan daerah. Program-program tersebut belum terlaksana dengan maksimal, karena tidak adanya Tim Literasi Sekolah. Implementasi Gerakan Literasi Sekolah di SMP Negeri 4 Kota Bengkulu masih berada pada tahap pembiasaan.
\end{abstract}

\section{Kata kunci: implementasi, Gerakan Literasi Sekolah}

\begin{abstract}
The purpose of this study was to describe the implementation ofGerakan Literasi Sekolah in SMP Negeri 4 Kota Bengkulu. This study uses descriptive method with a qualitative approach. The data obtained in the form of information about the implementation of Gerakan Literasi Sekolah and things that affect the implementation of Gerakan Literasi Sekolah. Data sources in this study were the principal, the deputy head of the curriculum, the head of the library, the Indonesian language teacher, and students. Data collection techniques using observation, interview, and documentation techniques.Data analysis techniques using 1) data reduction, 2) data presentation, and 3) conclusion/verification. The results showed that SMP Negeri 4 Bengkulu City had carried out several literacy programs, such as 1) activities 15 minutes reading nonlesson books, 2) journals of reading, 3) library visitors' awards, 4) reading corners and learning huts, and 5) regional library visits. These programs have not been implemented optimally, because there is no School Literacy Team. The implementation of Gerakan Literasi Sekolah in SMP Negeri 4 Kota Bengkulu is still in the habituation phase.
\end{abstract}

Keywords: implementation, Gerakan Literasi Sekolah 


\section{PENDAHULUAN}

Perkembangan teknologi dan informasi yang kian pesat menuntut individu untuk selalu mengembangkan kompetensi dirinnya. Hal tersebut telah ditegaskan dalam Forum Ekonomi Dunia tahun 2015 dan 2016, bahwa bangsa-bangsa di dunia harus merumuskan visi baru pendidikan yang berisikan literasi dasar, kompetensi, dan kualitas karakter. Sebagai salah satu keterampilan yang penting, literasi patut dimiliki oleh setiap orang.

Literasi dapat dimaknai sebagai kemampuan melek aksara yang mencakup kemampuan baca, tulis, dan berhitung (Calistung). Seseorang dapat dikatakan berliterasi jika ia memiliki kemampuan keberaksaraan. Namun Boeriswati (2016: 1)menganggap definisi literasi sebagai kemampuan keberaksaraan dinilai terlalu sempit, pemaknaan mengenai literasi terus berkembang sesuai dengan perkembangan ilmu pengetahuan dan teknologi. Menurutnya literasi merupakan kemampuan untuk menggunakan, memahami, mengreasikan, wacana yang dibaca dan mengomunikasikan secara fleksibel dalam berbagai situasi.

Berdasarkan penjelasan tersebut literasi merupakan sebuah kecakapan hidup yang kompleks. Kegiatan berliterasi memerlukan serangkaian aktivitas seperti memperoleh, menafsirkan, serta menggunakan sesuatu dalam kehidupan

sehari-hari dengan tujuan untuk mengembangkan dan mengolaborasikan kemampuan diri dengan lingkungannya.

Penggiatan praktik literasi tentunya memerlukan pembiasaan dan proses yang berkesinambungan. Setiap individu memerlukan penguasaan keterampilan dalam mengakses, mengolah, maupun mengomunikasikan hasil bacaannya. Sehingga dapat terciptanya kelompok masyarakat yang literat.

Hadirnya Gerakan Literasi Sekolah merupakan manifestasi dari Perarutan
Kementerian Pendidikan dan Kebudayaan nomor 23 tahun 2015 tentang Penumbuhan Budi Pekerti (PBP) yang bertujuan untuk membangun budaya literasi. Gerakan Literasi Sekolah merupakan sebuah upaya yang dilakukan secara menyeluruh untuk menjadikan sekolah sebagai organisasi pembelajaran yang warganya literat sepanjang hayat melalui pelibatan publik (Kemendikbud, 2016:2).

Konsep pendidikan yang warganya literat sepanjang hayat, sejalan dengan kewajiban setiap manusia untuk selalu menuntut ilmu dari buaian sampai ke liang lahat. Gerakan Literasi Sekolah diharapkan mampu memicu sikap dan perilaku positif di kalangan peserta didik.

Salah satu kegiatan yang terdapat dalam Gerakan Literasi Sekolah adalah kegiatan literasi 15 menit membaca buku nonpelajaran, yang sekarang menjadi fokus utama GLS. Kegiatan ini dilaksanakan dengan tujuan menumbuhkan minat baca serta meningkatkan keterampilan membaca peserta didik agar dapat menguasai informasi yang dibaca. Bahan bacaan berisi nilai-nilai seperti budi pekerti, kearifan lokal, cinta tanah air, yang sesuai dengan tahap perkembangan peserta didik.

Selain itu, peserta didik juga diminta untuk mengomunikasikan hasil bacaannya. Aktivitas tersebut bertujuan agar peserta didik terbiasa dengan berliterasi, baik dalam mengakses, mengolah, maupun mengomunikasikan informasi yang telah dibacaannya.

Kegiatan tersebut bertemali dengan pendapat Alwasilah (2012:166) menurutnya literasi bukan sekadar kemampuan membaca dan menulis, tetapi juga menggunakan bahasa itu secara fasih, efektif, dan kritis. Pada dasarnya, literasi tidak dapat dilepaskan dari kemampuan berbahasa. Seseorang dikatakan memiliki kemampuan literasi apabila ia telah memperoleh kemampuan berbahasa, baik 
menyimak, berbicara, membaca, maupun menulis.

Pemaknaan literasi sebagai kemampuan baca-tulis merupakan pintu utama bagi pengembangan makna literasi secara lebih luas. Peserta didik dituntut untuk memiliki kemampuan membaca dalam pengertian memahami teks secara analitis, kritis, dan reflektif serta mampu untuk mengomunikasikannya. Hal ini tentunya memerlukan keseriusan dalam upaya membangun budaya literasi di sekolah.

Pada tingkatan SMP di kota Bengkulu, hanya terdapat beberapa sekolah saja yang telah menerapkan Gerakan Literasi Sekolah. Hal tersebut terkait dengan sarana dan prasarana sekolah yang kurang memadai, seperti masih minimnya buku nonpelajaran. Kegiatan ini perlu ditunjang dengan penyediaan bahan bacaan yang memadai serta strategi pemanfaatan bahan pustaka yang cermat dan kreatif.

SMP Negeri 4 Kota Bengkulu merupakan salah satu sekolah yang telah melaksanakan Gerakan Literasi Sekolah. SMP Negeri 4 Kota Bengkulu juga telah melaksanakan kegiatan literasi 15 menit membaca buku nonpelajaran. Hal ini tentunya dapat menjadi contoh bagi sekolah lainnya untuk jenjang SMP di Kota Bengkulu.

Berdasarkan hal tersebut, peneliti tertarik untuk meneliti mengenai implementasi Gerakan Literasi Sekolah di SMP Negeri 4 Kota Bengkulu. Penelitian ini juga dapat menjadi rujukan khususnya untuk evaluasi pelaksanaan Gerakan Literasi Sekolah.

\section{METODE}

Penelitian ini menggunakan metode deskriptif kualitatif. Tempat penelitian dilakukan di SMP Negeri 4 Kota Bengkulu, jalan Cimanuk KM. 6,5 Kota Bengkulu.Data yang diperoleh berupa informasi mengenai pelaksanaan Gerakan Literasi Sekolah sertahal-hal yang mempengaruhi pelaksanaan Gerakan Literasi Sekolah.Sumber data pada penelitian ini yaknikepala sekolah, wakil kepala kurikulum, kepala perpustakaan, guru bahasa Indonesia, sertapeserta didik.Teknik pengumpulan data menggunakan teknik observasi, wawancara, dan dokumentasi. Teknik analisis data menggunakan model Miles dan Hubberman yang terdiri dari tiga komponen penting, yaitu (1) reduksi data, (2) penyajian data, dan (3) penarikan kesimpulan/verifikasi.

\section{HASIL PENELITIAN DAN PEMBAHASAN}

Berdasarkan hasil penelitian, SMP Negeri 4 Kota Bengkulu telah melaksanakan berbagai kegiatan literasi. Pertama, kegiatan 15 menit membaca buku nonpelajaran. Kegiatan ini dilaksanakan setiap hari selasa pagi, sebelum jam pelajaran dimulai. Waktu pelaksanaannya berlangsung selama 30 menit, dimulai pukul 07.15 WIB hingga 07.45 WIB.

Pada pengamatan tanggal 17 April 2018, kegiatan diawali dengan berbaris di depan kelas. Ketua kelas menyiapkan barisan dan mengecek kehadiran teman-temannya. Kemudian, peserta didik masuk satu persatu dan duduk di tempatnya masingmasing. Guru yang mengajar baru tiba di kelas dan langsung memasuki kelas. Kemudian, ketua kelas menyiapkan kelas, memberi salam kepada guru lalu berdoa.

Ketika kegiatan 15 menit membaca buku nonpelajaran dimulai, kondisi sekolah menjadi gaduh. Hal ini disebabkan karena terdapat beberapa peserta didik yang tidak membawa buku nonpelajaran. Peserta didik berlarian menuju perpustakaan untuk meminjam buku, sehingga lingkungan menjadi kurang kondusif. Namun, sebagian guru tidak mengizinkan dan menyuruh peserta didik agar membaca bersama teman yang membawa buku,

Setelah itu, peserta didik mulai membaca buku nonpelajaran. Beberapa peserta didik membaca sebuah buku 
nonpelajaran secara bersama-sama, sedangkan yang lainnya membaca buku sendiri-sendiri. Buku bacaan peserta didik beragam, seperti komik, dongeng, kisah sahabat nabi, ensiklopedia, cerpen, dan novel.

Pada saat kegiatan membaca berlangsung, guru di kelas hanya mengawasi dan tidak ikut membaca. Para guru yang sedang tidak mengajar juga tidak ikut membaca, mereka sibuk dengan kegiatannya masing-masing.

Setelah kegiatan membaca, guru menunjuk peserta didik untuk menceritakan hasil bacaannya. Selama kegiatan berlangsung tidak terjadi interaksi, baik antara guru dan peserta didik maupun peserta didik dengan peserta didik lainnya. Peserta didik hanya membaca buku nonpelajaran, dan menceritakannya kembali. Setelah kegiatan berakhir, guru langsung melanjutkan dengan pembelajaran.

Hal tersebut sedikit berbeda dengan pengamatan selanjutnya yang dilakukan pada tanggal 8 Mei 2018. Pada pengamatan kedua, guru yang mengajar pada jam pertama masuk kelas lebih awal. Seluruh peserta didik langsung duduk di tempatnya masing-masing tanpa berbaris di depan kelas. Ketika bel berbunyi, ketua kelas menyiapkan kelas dengan memberi salam kepada guru dan berdoa,

Meskipun begitu, masih banyak peserta didik yang tidak membawa buku nonpelajaran. Mereka langsung membaca buku bersama teman mereka yang membawa buku nonpelajaran.Ketika kegiatan berlangsung, para guru hanya mengawasi dan tidak ikut membaca. Setelah kegiatan membaca, tidak ada kegiatan tindak lanjut. Guru langsung melanjutkan dengan pembelajaran.

SMP Negeri 4 Kota Bengkulu telah menerapkan kegiatan 15 menit membaca buku nonpelajaran selama 2 tahun, sejak Permendikbud nomor 23 tahun 2015 tentang Penumbuhan Budi Pekerti diterbitkan. Pada awal pelaksanaannya, SMP Negeri 4 Kota Bengkulu melaksanakan kegiatan 15 menit membaca buku nonpelajaran seminggu dua kali, yakni pada hari selasa dan hari kamis. Namun, ketika sekolah telah menerapkan Full Day School, kegiatan 15 menit membaca buku nonpelajaran hari kamis diganti dengan kegiatan senam. Sehingga kegiatan kegiatan 15 menit membaca buku nonpelajaran hanya satu kali.

Kemudian, mengenai waktu pelaksanaan kegiatan 15 menit membaca buku nonpelajaran. Peserta didik mengeluhkan waktu kegiatan yang hanya 30 menit. Bagi peserta didik, waktu 30 menit masih terlalu singkat. Karena waktu kegiatan yang singkat juga digunakan untuk merangkum hasil bacaan.

Persoalan tersebut juga mempengaruhi keterlibatan peserta didik. Selama kegiatan 15 menit membaca buku nonpelajaran berlangsung, keterlibatan peserta didik dalam mengikuti kegiatan cenderung pasif. Peserta didik masih perlu dorongan dari guru agar mau membaca buku, peserta didik juga perlu dipancing dengan pertanyaan-pertanyaan yang menarik agar mereka mau merespon.

Kedua, peserta didik di SMP Negeri 4 Kota Bengkulu memiliki jurnal membaca. Pemantauan dilakukan oleh guru bahasa Indonesia dengan cara menuliskan hasil bacaannya ke dalam sebuah buku catatan (buku jurnal membaca) untuk diperiksa oleh guru bahasa Indonesia setiap 1 bulan sekali.

Isi dari jurnal membaca peserta didik hanya berupa rangkuman dari buku yang telah dibaca, bukan berupa komentar atau tanggapan. Format penulisannya juga tidak menggunakan graphic organizers seperti yang dicontohkan pada Panduan Gerakan Literasi Sekolah di SMP. Buku yang dibaca oleh peserta didik selama satu tahun hanya 2-3 buku nonpelajaran. 
Ketiga, perpustakaan sekolah memiliki program yaitu penghargaan terhadap peserta didik yang rajin berkunjung ke perpustakaan. Kemudian, setiap tahunnya kelas sembilan menyumbang buku ke perpustakaan sekolah. Buku yang diutamakan untuk disumbang oleh kelas IX adalah buku fiksi. Karena, selain banyaknya peserta didik yang suka membaca buku fiksi, buku fiksi di perpustakaan sekolah masih minim jika dibandingkan dengan buku nonfiksi. Buku fiksi hanya sekitar 1.350 buku, sedangkan nonfiksi 1.500-an.

Penyediaan buku yang beragam di perpustakaan sekolah tentunya akan mempermudah peserta didik dalam mengakses/memperoleh bahan bacaan. Peserta didik dapat meminjam buku yang ia sukai untuk dibaca pada kegiatan 15 menit membaca buku nonpelajaran. Peserta didik juga dapat menggunakannya untuk mengembangkan kemampuan literasinya secara mandiri.

Keempat, SMP Negeri 4 Kota Bengkulu memiliki sudut baca di setiap kelas. Penyediaan sudut baca di kelas tidak diikuti dengan penciptaan lingkungan yang ramah dan menyenangkan bagi peserta didik untuk membaca. Sudut baca di kelas hanya berupa lemari kecil untuk peserta didik menyimpan buku bacaannya.

SMP Negeri 4 Kota Bengkulu juga memiliki pondok belajar di beberapa sudut sekolah, satu di dekat mushola, satu terletak di sebelah rumah kompos, dan satu lagi di sebelah kebun sekolah. Lingkungan pondok belajar bersih dan nyaman untuk dimanfaatkan berbagai kegiatan literasi, namun tidak dilengkapi dengan sumber-sumber bacaan.

Kelima, kunjungan perpustakaan daerah. SMP Negeri 4 Kota Bengkulu melakukan kerja sama dengan Dinas Perpustakaan Daerah untuk menyukseskan Gerakan Literasi Sekolah. Sekolah mendatangkan buku dari Perpustakaan Daerah ke sekolah menggunakan mobil perpustakaan keliling.
Perpustakaan Daerah datang setiap dua minggu sekali pada hari kamis.

Pada pelaksanaannya, berbagai kegiatan literasi tersebut belum terlaksana dengan baik.Berbagai kendala menghambat pelaksanaan Gerakan Literasi Sekolah.

Berdasarkan pengamatan pertama dan kedua, terdapat beberapa persamaan dan perbedaan di dalam pelaksanaan kegiatan 15 menit membaca buku nonpelajaran. Pada pengamatan pertama, beberapa peserta didik tidak membawa buku nonpelajaran. Peserta didik yang tidak membawa buku berlarian hendak meminjam buku ke perpustakaan, tetapi beberapa guru menyuruh mereka untuk membaca bersama-sama dengan peserta didik yang membawa buku. Pada pengamatan kedua masih terdapat beberapa peserta didik yang tidak membawa buku nonpelajaran, tetapi mereka langsung membaca buku bersama teman mereka yang membawa buku nonpelajaran.

Hal ini menunjukkan bahwa belum adanya kesadaran yang baik dari peserta didik. Priyatni (2010:27) berpendapat bahwa literasi kritis berkaitandengan berpikir kritis dan kesadaran kritis. Seseorang tidak langsung memiliki kemampuan literasi tanpa adanya kesadaran lebih dahulu, yakni kemampuan mengenali kondisi.

Berdasarkan hal tersebut, peserta didik belum mampu mengenali kondisinya dengan baik. Kondisi yang dimaksud adalah bahwa setiap hari selasa, peserta didik harus membawa buku nonpelajaran untuk mengikuti kegiatan literasi. Hal tersebut juga dapat disebabkan karena tidak semua peserta didik suka membaca buku. Peserta didik merasa terpaksa untuk membaca buku yang bukan kebiasaannya.

Kemudian pada saat pengamatan pertama, guru menyuruh peserta didik untuk membaca dan dilanjutkan dengan menceritakan kembali hasil bacaannya di 
depan kelas. Sedangkan pada pengamatan kedua, guru hanya menyuruh peserta didik untuk membaca dan langsung belajar tanpa adanya kegiatan tindak lanjut. Ketika kegiatan berlangsung tidak terjadi interaksi yang berarti, baik antara peserta didik dan guru maupun peserta didik dengan peserta didik.

Kegiatan 15 menit membaca buku nonpelajaran belum mampu mengembangkan kolaborasi. Kern (Wulandari, 2017:25) berpendapat bahwa salah satu komponen literasi adalah kolaborasi, yaitu terdapat kerja sama antara dua pihak yakni penulis dan pembaca atau pembicara dan pendengar. Pengertian penulis dan pembaca atau pembicara dan pendengar dalam hal ini adalah guru dan peserta didik. Sedangkan kerjasama yang dimaksud adalah upaya dalam mencapai suatu pemahaman bersama. Guru dan peserta didik secara bersama-sama menyimpulkan hasil bacaan mereka.

Selain itu, kegiatan 15 menit membaca buku nonpelajaran juga belum memenuhi salah satu prinsip literasi sekolah, yakni literasi mengembangkan budaya lisan. Seharusnya dalam kegiatan 15 menit membaca buku nonpelajaran terjadi interaksi positif, baik antara guru dan peserta didik maupun antar peserta didik. Kegiatan berupa diskusi (bincang buku) dapat membangun keterikatan emosi antara guru dan peserta didik, dan dapat memotivasi peserta didik untuk terus membaca.

Kegiatan diskusi seperti ini perlu dikembangkan dalam kegiatan 15 menit membaca buku nonpelajaran. $\mathrm{Hal}$ ini berkenaan dengan tindak lanjut yang diberikan oleh guru, yaitu hanya berupa menceritakan kembali hasil bacaan atau menuliskan rangkuman bacaan bukan berupa tanggapan. Berdasarkan jurnal membaca, peserta didik hanya membaca 23 buku nonpelajaran saja. Padahal, dalam
Kurikulum 2013, peserta didik SMP wajib menyelesaikan minimal 12 buku nonpelajaran/pengayaan (Kemendikbud, Manual Pendukung Pelaksanaan Gerakan Literasi Sekolah untuk Jenjang Sekolah Menengah Pertama, 2016:18).

Kegiatan tindak lanjut belum mampu mengembangkan kemampuan literasi peserta didik dengan baik. Alwasilah (2012:166) mengemukakan bahwa literasi bukan sekadar kemampuan membaca dan menulis, tetapi juga menggunakan bahasa itu secara fasih, efektif, dan kritis. Seharusnya, dalam kegiatan tersebut terdapat tindak lanjut seperti diskusi, bertukar pikiran, menanggapi hasil simpulan peserta didik. Sehingga mampu mengembangkan kemampuan peserta didik untuk menggunakan bahasa secara fasih, dan efektif melalui kegiatan berpikir kritis tentang ide-ide.

Oleh karena itu, perlu adanya kegiatan diskusi. Kegiatan diskusi yang dimaksud adalah kegiatan yang mampu membuka kemungkinan untuk perbedaan pendapat untuk menyampaikan perasaan dan pendapatnya, saling mendengarkan, dan menghormati perbedaan pandangan (Kemendikbud, 2016:12).

Keikutsertaan peserta didik dalam kegiatan literasi di kelas masih cenderung pasif. Peserta didik masih perlu dorongan dari guru, baik berupa umpan pertanyaan maupun ajakan atau perintah. Guru juga perlu mengembangkan strategi membaca seperti mengolaborasikan strategi membaca dalam hati dan membaca nyaring. Peserta didik membaca dalam hati sedangkan guru membacakan buku dengan nyaring.

Namun, guru justru belum menjadi model yang baik. Pada saat kegiatan membaca, guru tidak ikut membaca buku. Perihal ini, guru hanya sesekali mengawasi peserta didik dan lebih sering keluar kelas atau memainkan gawainya. Hal ini tentunya juga menjadi problem kegiatan literasi, 
yakni guru tidak hadir (ikut membaca) ketika peserta didik membaca.

Salah satu yang menjadi masalah dalam kegiatan literasi di SMP 4 Kota Bengkulu bukan terletak pada ketiadaan buku, melainkan ketiadaan guru untuk ikut membaca bersama peserta didik. Hal ini seperti yang dikemukakan oleh Antoro (2017:43), bahwa guru seharusnya tidak hanya mengawasi aktivitas peserta didik, tetapi menjadi model yang baik dengan ikut serta membaca buku.

Berdasarkan hal tersebut, perlu digiatkannya praktik-praktik literasi di sekolah. Penggiatan praktik literasi menuntut setiap orang untuk memandang literasi sebagai kebutuhan serta mempergunakannya secara kritis. Pembelajaran literasi di sekolah-sekolah pun harus mendorong peserta didik maupun guru untuk berpikir kritis dan kreatif.

Selanjutnya mengenai waktu kegiatan literasi. Berkenaan dengan hal tersebut, kebijakan Full Day School sebenarnya sedikit bertentangan dengan prinsip dari Gerakan Literasi Sekolah. Kebijakan Full Day School memaksa peserta didik untuk belajar satu hari penuh, sementara GLS berupaya untuk membiasakan peserta didik agar rutin membaca setiap hari, sekalipun dengan waktu yang singkat.

Janice L. Pilgreen (Kemendikbud, 2017:34) berpendapat bahwa persoalan pokok yang dihadapi oleh guru agar peserta didik gemar membaca bukanlah pada durasi waktu membaca, melainkan frekuensi dari kegiatan membaca. Kegiatan membaca yang terlalu lama justru akan membuat peserta didik merasa bosan, terutama bagi peserta didik yang belum terbiasa membaca.

Persoalan waktu dalam kegiatan literasi sebenarnya bukan masalah yang rumit, tinggal bagaimana guru/sekolah dapat memanfaatkan waktu yang singkat dipergunakan untuk berbagai kegiatan yang bermakna. Sehingga, dapat diperoleh hasil yang maksimal dari kegiatan 15 menit membaca buku nonpelajaran.

Tujuan dari kegiatan 15 menit membaca sebelum jam pelajaran adalah menjadikan peserta didik menyukai kegiatan membaca dengan cara melakukan kegiatan membaca secara berulang-ulang dan setiap hari. Pilgreen (Kemendikbud, 2017:34) mengemukakan bahwa kunci utama membentuk peserta didik yang gemar membaca ialah menjadikan membaca sebagai kegiatan reguler peserta didik.

Kemudian, setelah kegiatan membaca menjadi kegiatan reguler, maka diberikan tindak lanjut. Pada pelaksanaan di SMP Negeri 4 Kota Bengkulu, tindak lanjut diberikan oleh guru Bahasa Indonesia. Kegiatan 15 menit sebelum jam pelajaran memiliki jadwalnya tersendiri di luar jam pelajaran. Kegiatan terjadwal tentunya akan mudah untuk dipantau pelaksanaan dan perkembangannya, serta dapat dievaluasi.

Hal tersebut telah sesuai seperti yang tercantum dalam buku Desain Induk Gerakan Literasi Sekolah. Bahwa pada pelaksanaannya, setiap periode tertentu yang terjadwal, dilakukan asesmen agar dampak dari Gerakan Literasi Sekolah dapat dipantau dan terus-menerus dikembangkan (Kemendikbud, 2016:8). Jadi, sekolah menjadwalkan dan memantau kegiatan untuk dapat melakukan evaluasi demi pengembangan Gerakan Literasi Sekolah.

Meskipun begitu, pemantauan dan pengembangan dari kegiatan literasi seperti hanya menekankan tanggung jawab kepada guru Bahasa Indonesia saja. Hal ini sedikit bertentangan dengan prinsip literasi sekolah, yaitu terintegrasi dengan kurikulum. Bahwa pembiasaan dan pembelajaran literasi disekolah adalah tanggung jawab semua guru di semua mata pelajaran, sebab pembelajaran mata pelajaran apapun membutuhkan bahasa, 
terutama membaca dan menulis (Kemendikbud, 2016:11).

Jadi, pemantauan dan pengembangan kegiatan literasi di sekolah bukan sematamata hanya tanggung jawab guru Bahasa Indonesia. Semua guru mata pelajaran juga ikut bertanggung jawab dan terlibat dalam kegiatan literasi di sekolah. Maka dari itu. pengembangan profesional guru dalam hal literasi juga perlu diberikan kepada semua guru mata pelajaran.

Persoalan tersebut berkenaan dengan tidak adanya Tim Literasi Sekolah. Kegiatan literasi hanya dibebankan kepada sebagian guru, seperti Kepala Sekolah sebagai penanggung jawab, Wakil Kepala Akademik sebagai pengelola, dan guru Bahasa Indonesia sebagai pelaksana. Padahal sasaran dari Gerakan Literasi Sekolah adalah seluruh ekosistem sekolah, baik kepala sekolah, pendidik, tenaga kependidikan (pustakawan), maupun peserta didik (Kemendikbud, 2016:5).

Menurut Pilgreen (Kemendikbud, 2016:1) program membaca bebas (literasi) tidak cukup hanya sekadar menyediakan waktu tertentu (misalnya lima belas menit setiap hari) bagi peserta didik untuk membaca. Sekolah perlu memastikan bahwa seluruh warga sekolah memiliki persepsi dan pemahaman yang sama tentang prinsip-prinsip kegiatan membaca bebas, serta bagaimana cara pelaksanaan dan pengelolaan program agar program membaca bebas dapat berjalan dengan baik.

Berdasarkan hal tersebut, dapat diketahui bahwa pentingnya dibentuk Tim Literasi Sekolah atau sejenisnya yang mengatur kegiatan literasi di sekolah. Struktur Organisasi TLS di Sekolah terdiri atas Ketua TLS (guru) dan anggota (minimal ada pengurus perpustakaan/taman baca sekolah dan guru lain). Posisi TLS dalam Struktur Organisasi Sekolah setara dengan Tim Adiwiyata sekolah.
Selain itu, bagi guru dan tenaga kependidikan yang akan menjadi Tim Literasi Sekolah juga penting dilakukan pelatihan staf. Tujuan dari pelatihan staf adalah untuk membantu para guru dalam membuat dan menyepakati petunjuk praktis pelaksanaan program membaca, serta menjalankan perannya sebagai fasilitator yang membantu peserta didik agar terhubung secara emosi dan pikiran dengan buku (Kemendikbud, 2016:1).

Kemudian, sarana dan prasarana yang menunjang Gerakan Literasi Sekolah di SMP Negeri 4 Kota Bengkulu. Sarana dan prasarana yang dimaksud adalah perpustakaan sekolah dan pondok belajar. Suasana dan kondisi perpustakaan sekolah dan pondok belajar SMP Negeri 4 Kota Bengkulu cukup nyaman dan bersih.

Perpustakaan sekolah juga memiliki program yakni memberikan penghargaan terhadap peserta didik yang rajin berkunjung ke perpustakaan. Kegiatan ini bertujuan agar peserta didik mau memanfaatkan perpustakaan untuk menumbuhkan kegemaran membaca.Perihal tersebut, sekolah hanya memberi penghargaan kepada peserta didik yang sering berkunjung ke perpustakaan sekolah saja, tanpa adanya kegiatan yang berarti. Maksudnya, sekolah hanya memberikan dorongan kepada peserta didik untuk berkunjung ke perpustakaan sekolah, dengan harapan mendapatkan reward.

Selain itu, fasilitas pondok belajar belum dimanfaatkan dengan baik. Pondok belajar yang seharusnya dapat dimanfaatkan untuk berbagai kegiatan literasi, hanya dijadikan tempat beristirahat oleh peserta didik saat jam istirahat atau setelah berolahraga. Oleh karena itu, pengelola perpustakaan sekolah hendaknya menyusun kegiatan yang mampu mendorong agar seluruh peserta didik mau berkunjung ke perpustakaan. Salah satu kegiatan yang 
bisa diterapkan adalah jadwal kunjung ke perpustakaan sekolah.

Kegiatan ini mengharuskan peserta didik untuk sering membaca buku di perpustakaan sekolah. Pengelola perpustakaan memberikan jadwal kunjung ke perpustakaan kepada setiap guru mata pelajaran. Kemudian, setiap guru mata pelajaran membawa peserta didik satu kelas untuk berkunjung ke perpustakaan sesuai dengan jadwal (Kemendikbud, 2016:20).

Kegiatan tersebut juga dapat memanfaatkan pondok belajar, sebagai tempat membaca. Tujuan dari kegiatan tersebut adalah mendorong dan membiasakan seluruh peserta didik agar rutin membaca, baik di kelas maupun di luar kelas. Sehingga peserta didik dapat benar-benar memanfaatkan fasilitas sekolah yang ada untuk menunjang kemampuan literasinya.

SMP Negeri 4 Kota Bengkulu juga bekerja sama dengan Dinas Perpustakaan Daerah untuk mendatangkan buku dari perpustakaan daerah menggunakan mobil perpustakaan. Hal ini tentunya akan menarik minat peserta didik serta memperbanyak koleksi bacaan mereka.

Pada pelaksanaannya, perpustakaan sekolah beberapa kali tidak datang ke sekolah karena memiliki kesibukan. Kendala semacam ini seharusnya dapat diantisipasi oleh pihak sekolah. Sekolah tidak boleh hanya tepaku dengan satu kegiatan. Sekolah perlu mengembangkan berbagai kegiatan yang juga dapat menumbuhkan minat peserta didik tehadap buku. Beberapa contoh kegiatan yang dapat dilakukan adalah memanfaatkan/mengadakan pameran buku atau kunjungan perpustakaan di luar sekolah.

Guru dapat mengadakan kegiatan kunjungan ke perpustakaan kota/daerah untuk mendekatkan peserta didik dengan sumber informasi. Kegiatan seperti ini bermanfaat untuk menambah wawasan peserta didik mengenai jenis-jenis buku, mengenal dan menggunakan sumber informasi selain buku, serta mengenal dan memanfaatkan peran pustakawan (Kemendikbud, 2016:33).

Sekolah juga bisa mendekatkan peserta didik dengan buku, dengan memanfaatkan pameran buku yang sering diadakan di kota di mana sekolah berada. Biasanya dalam pameran buku, banyak buku dijual murah, dan peserta didik atau sekolah dapat menambah koleksi buku. Apabila memungkinkan, sekolah dapat juga mengadakan pameran buku pada saat-saat tertentu (Kemendikbud, Panduan Gerakan Literasi di Sekolah Menengah Pertama, 2016:35).

\section{PENUTUP}

\section{Kesimpulan}

SMP Negeri 4 Kota Bengkulu telah melaksanakan beberapa program literasi, seperti kegiatan 15 menit membaca buku nonpelajaran, jurnal membaca, penghargaan pengunjung perpustakaan, sudut baca dan pondok belajar, serta kunjungan perpustakaan daerah. Programprogram tersebut belum terlaksana dengan maksimal, karena tidak adanya Tim Literasi Sekolah yang bertugas mengelola, memantau, serta mengevaluasi pelaksanaannya.

Berdasarkan hasil penelitian dan pembahasan, maka dapat disimpulkan bahwa implementasi Gerakan Literasi Sekolah di SMP Negeri 4 Kota Bengkulu masih berada pada tahap pembiaasaan. Hal ini juga berdasarkan indikator Budaya Literasi Sekolah.

\section{Saran}

Seluruh guru mata pelajaran perlu ikut terlibat dalam kegiatan 15 menit membaca buku nonpelajaran. Kegiatan tersebut dapat dijadikan bahan penilaian dalam pembelajaran melalui tagihan nonakademik 
maupun tagihan akademik. Sehingga, kegiatan belajar mengajar (KBM) secara bertahap menjadi berbasis literasi.

Kemudian, sekolah perlu membentuk Tim Literasi Sekolah yang mengelola, mengembangkan, dan memantau kegiatan literasi di sekolah. Sekolah juga perlu mengembangkan berbagai kegiatan seperti perayaan hari-hari tertentu atau hari nasional dengan bertemakan literasi, perlombaan dengan tema literasi, serta mengundang tokoh-tokoh inspiratif dan melakukan diskusi bersama.

\section{DAFTAR PUSTAKA}

Alwasilah, A. C. 2012. Pokoknya Rekayasa Literasi. Bandung: Kiblat.

Antoro, B. 2017. Gerakan Literasi Sekolah dari pucuk hingga akar sebuah refleksi. Jakarta: Kementerian Pendidikan dan Kebudayaan.

Boeriswati, E. 2016. "Pedidikanan Literasi Abad 21". Makalah yang disajikan dalam Kuliah Umum Pembelajaran Literasi Abad 21 yang dilaksanakan Pascasarjana S2 Pendidikan Bahasa Indonesia. Gedung Aula FKIP. Universitas Bengkulu. Tanggal 8 Oktober 2016.
Kemendikbud. 2016. Desain Induk Gerakan Literasi Sekolah. Jakarta: Direktorat Jenderal Pendidikan Dasar dan Menengah Kementerian Pendidikan dan Kebudayaan.

Kemendikbud. 2016. Manual Pendukung Pelaksanaan Gerakan Literasi Sekolah untuk Jenjang Sekolah Menengah Pertama. Jakarta: Direktorat Jenderal Pendidikan Dasar dan Menengah Kementerian Pendidikan dan Kebudayaan.

Kemendikbud. 2016. Panduan Gerakan Literasi di Sekolah Menengah Pertama. Jakarta: Direktorat Jenderal Pendidikan Dasar dan Menengah Kementerian Pendidikan dan Kebudayaan.

Priyatni, E. T. 2010. Membaca Sastra dengan Ancangan Literasi Kritis. Malang: Bumi Aksara

Wulandari. R. 2016. Implementasi Kebijakan Gerakan Literasi Sekolah Di Sekolah Dasar Islam Terpadu Lukman Al Hakim Internasional. Yogyakarta: Universitas Negeri Yogyakarta. 